\title{
Analysis and Development of Learning Plans Using Project Based Learning Model in Fostering 4 Cs Skills of Economics Education Students
}

\author{
Yulhendri $^{*}$, Rani Sofya ${ }^{2}$ Mentari Ritonga ${ }^{3}$ \\ 1,2,3 Universitas Negeri Padang, Padang, Indonesia \\ ${ }^{*}$ Corresponding author.Email: yulhendri@fe.unp.ac.id
}

\begin{abstract}
Young generations in the 21st century demand a special skill which is different from the previous generation. As a matter of fact, the young generations live in the digital, the internet, the industrial revolution, and disruptive innovation eras. Besides, recently the world is attacked by a pandemic virus called the Covid-19 virus. The American Management Association (AMA) in 2012 developed a concept called super skills 4 Cs (Creativity, Critical thinking, Communication, Collaboration) in 3 main areas, namely: 1) Learning and innovation skills: critical thinking and problem solving, communication and collaboration, creativity and innovation, 2) Digital literacy skills: information literacy, media literacy, information and communication technology literacy, and 3) career and life skills: flexibility and adaptability, self-initiative and direction, social and cross-cultural interactions, productivity and accountability. This paper discussed about preparation of a learning plan through Project-Based Learning as an effort to improve the students' 4Cs skill, particularly students who are taking Economics Education Study Program. It is important to identify the activities of lecturers and students so that the achievement of 4Cs can be done optimally in strengthening the learning design using distance learning methods with various e-learning applications.
\end{abstract}

Keywords: Strategy, Creativity, Critical thinking, Communication, Collaboration.

\section{INTRODUCTION}

The skills demand of the workforce globally has changed dramatically in the last 20 years. Many studies have shown that work routines have decreased; however, at the same time, there has been a rapid increase in work involving irregular activities, analytics and interactive communication skills. Moreover, today's job market requires competencies such as critical thinking and the ability to interact with people from a wide variety of linguistic and cultural backgrounds. Recently, individuals are required to think critically in order to be able to examine evidence, evaluate, and make logical decisions. In the business world, employees must think critically to better serve customers, develop better products, and continuously improve themselves in an ever-changing global economy. Students as prospective employees or business actors in the global economic era need special skills to be able to successfully complete their education, and enter the work field which has a high level of competition and challenges in carrier. Therefore, every individual must have the specific skills which in this case are the 4Cs (Creativity, critical thinking, communication, and collaboration). The education system must be able to produce graduates who have high competence and the 4Cs skills. The 4Cs thinking habits highly possibly determine the success of a student in education, career and life.

The demands for the growth of students' 4Cs skills must be obtained through learning experiences carried out in class. Students will not be well-prepared to face competition in education and the work field unless the schools implement new strategies that support learning that are able to prepare students as global citizens and workers. In fact, learning activities in the class (at undergraduate level), at the Faculty of Economics are usually in the form of lectures, seminars, group discussions, class discussions, assignments, and field/ industry visits. These activities generally aim to achieve learning outcomes; yet, these do not provide the expected outcome on 4Cs skills (Creativity, critical thinking, communication, collaboration) which are still low. Therefore, this study attempted to assess and implement a suitable strategy to improve the 4Cs skills in learning. This study examined the lecturers' and students' activities that can encourage the growth of 4Cs skills in the classroom. It is important to identify the activities of lecturers and students so that the 
achievement of $4 \mathrm{Cs}$ can be maximized in order to develop suitable learning methods and suitable learning syntax.

This study was conducted to find methods and suitable learning steps for encouraging the growth of $4 \mathrm{Cs}$ skills in learning at the undergraduate level (S1). The objectives of this study are: 1) identifying students' learning experiences that encourage the growth of $4 \mathrm{Cs}$ skills, 2) identifying lecturers' activities that encourage the growth of $4 \mathrm{Cs}, 3$ ) identifying the effect of implementing a strategy with certain learning steps on the growth of 4Cs skills, 4) identifying whether there is any interaction between learning achievement with the learning method.

This study is necessary to obtain a learning strategy which fosters creativity, critical thinking, communication, collaboration (4Cs) among Economics students as prospective economics teachers in the era 4.0. It is very relevant to the themes and research topics developed by Universitas Negeri Padang in 2020-2024, namely the superior theme of the learning model in IRE (Industrial Revolution Era) 4.0 with the topic of HOTS Learning Model (Higher Order Thinking Skills). The results of this study will be one of the recommendations related to the appropriate learning experience and lecturers' activities to be implemented in order to foster $4 \mathrm{Cs}$ in students so that students become highly competitive graduates in business, industry, and the other fields of work.

\subsection{Creativity, Critical Thinking, Communication \& Collaboration Skills (4Cs)}

It is extremely important to cultivate Creativity, Critical Thinking, Communication \& Collaboration Skills (4CS) as citizens and potential global workers. Furthermore, thinking habits such as analytical, interpretation, precision and accuracy, problem solving and reasoning skills are more important than content knowledge to determine a person's success in their study. 4Cs skills are necessary to develop the student quality in order to be successful in study, careers and as citizens in the 21 st century. Besides, both in university and work field the competitive level will be high; thus, students need 4Cs skills in order to keep up with the competitive and big challenges that they face.

Assessment and Teaching of 21 st Century categorize 21 st century skills into 4 categories, namely way of thinking, way of working, tools for working, and skills for living in the world. The way of thinking includes creativity, innovation, critical thinking skills, problem solving abilities, and decision making. Moreover, skills in communicating, collaborating and working in teams are included in the way of working. Tools for working consist of awareness of being a global as well as local citizen, and being responsible as a social person. Besides, skills for living in the world are skills based on information literacy, mastery of technology, and the ability to learn and work through digital social networks [1].

According to [2] 4Cs skills are a term for skills required by students to be successful in education, work and life. In order for educational institutions to produce graduates who can live and work productively in an increasingly complex and dynamic society, learning, teaching, assessment and curriculum need to equip graduates with skills that will enable them to contribute effectively to the productive capacities of 21 st century economy.

Critical Thinking is the ability of each student to compare and evaluate facts and opinions and make decisions based on the analysis carried out. Critical Thinking can be demonstrated from the student's ability to answer unexpected questions. Moreover, critical thinking skills can be trained in the following ways [3] : 1) carrying out questions and answers and discussions where the teacher first designs question items in the form of questions such as Socratic dialogue which is considered capable of maximizing HOTs [4], 2) teaching by connecting the concepts of the material learnt and using it as a source of questions; 3) providing scaffolding where the teacher helps students understand the concepts or questions asked and opportunities for students to learn independently.

The ability to think critically can be improved through various learning strategies implemented by teachers such as the integration of STAD and TPS [5], implementation of snowballing and numbered head together strategies, application of TTQ (Thinking Through Questions) pattern of inquiry method [6], inquiry method combined with reciprocal teaching, problem-based learning with the STAD model of cooperative strategy [7], and problem solving-based learning, project-based learning and others.

In addition, creativity is the ability to evaluate new ideas that contain 1) originality, 2) usability, and 3) novelty that generate innovation to address needs and problems in a very complex and rapidly changing world [8]. Meanwhile, creative thinking is the ability to make connections between relationships that have not been made and generate new and original thoughts and experiences as new patterns in schemes [9]. Furthermore, collaboration is the ability to work in teams and collaborate productively. It occurs when two or more people work together to achieve a common goal. Usually, students can work with partners in small groups to investigate and collaborate on learning materials and other related topics.

Communication is the ability to articulate thoughts and ideas effectively using spoken, written, and nonverbal communication skills in various forms and contexts. To build effective communication skills, students must learn how to communicate using media to support personal and group learning, share information efficiently and effectively using appropriate media, and 
communicate thoughts and ideas clearly and effectively to audiences.

From above-mentioned elaboration of 4 Cs skills, it is concluded that these skills are mandatory to face competition in this century. Students must have critical thinking skills, creative thinking, collaboration, and communication skills to compete in an international competitive environment. Besides, schools are also required to integrate these skills into the core academic area of instruction. These skills must be an integral part of teaching and learning to ensure highly effective teaching and make learning more rigorous and relevant. Incorporating the $4 \mathrm{Cs}$ into education defines a strong learning environment, resulting in emerging students with the skills necessary to become successful citizens and leaders of tomorrow. For that reason, we need a learning model that is able to develop 4Cs skills simultaneously in a learning process.

\subsection{Project Based Learning (PJBL)}

Project Based Learning is an innovative learning model that focuses more on the learning process on contextual learning through complex activities [10]. In Project Based Learning, the involvement of students is the key in which the students are directed to learn knowledge and skills through a structured process, and real and thorough experiences which are designed to produce a product. Nevertheless, PJBL is very rarely implemented due to the fact that it requires sufficient preparation and much time to work on. Moreover, PJBL aims to focus students on complex problems so that an in-depth investigation is needed in understanding learning [11]. This model also aims to guide students in a collaborative project so that it can provide opportunities for students to explore material using various meaningful ways.

As for the first step, Project Based Learning uses problems in collecting and integrating students' new knowledge based on real experiences and activities [12]. This model is a learning method in the form of presenting material to students with a starting point of a problem which is then discussed from various relevant sides so that a comprehensive and meaningful solution is obtained [13].

According to [12], Project Based Learning has several advantages which are 1) increasing the students' motivation and learning ability in problem solving, 2) making students more active, 3 ) increasing collaboration among students, 4) encouraging students to develop and practice communicative skills, 5) providing experiences in organizing projects, including allocating time and sources of information in completing tasks, 6) providing learning experiences that involve students in a complex manner which is designed in accordance with the real world.

Despite the fact that Project Based Learning practices provide opportunities for students, the learning process must be thoroughly planned, arranged, and assessed to link academic content with 21 st Century Skills (such as $4 \mathrm{Cs})$ through quality development, authentic products, and presentation [14]. This model is a model that is able to bridge the achievement of 4Cs skills in learning [15]. Besides, it also helps students learn core subject matter and practice collaboration, communication \& critical thinking skills [16]. Additionally, according to [17], the implementation of Project Based Learning can further encourage students' problem-solving skills to achieve higher levels of achievement in physics mechanical tests. Study conducted by [18] revealed that 4Cs-based Project-Based Learning model had a significant effect on students' learning independence and reading comprehension skills. Based on evidences, it can be concluded that the Project Based Learning model is considered capable of providing a separate space for students to be more active in solving problems so that students acquire new knowledge and skills, train collaboration or group collaboration in organizing projects, increase student creativity in seeking and manage information and carry out the project work process. Therefore, PJBL is considered very suitable for developing 4Cs skills. From the several previous studies conducted, none of them has specifically shown the effect of the application of PJBL on improving the 4Cs skills of students as prospective teachers. That is why this study focused on the implementation of Project Based Learning in improving students' 4Cs skills. So, this study is very important to do in order to produce graduates who have the skills to be successful in facing competition in the 4.0 era.

\section{METHOD}

This paper is the result of study which tested the validity of the contents of a project-based learning plan. The material content was thoroughly reviewed by 3 experts who have sufficient competence to assess learning content. They are practitioners of economic education who have experience in teaching.

Furthermore, the result obtained will be further studied by doing experimental research with a factorial design. Experimental research is a method used to find the effect of certain treatments on others under controlled conditions. A design in which the researcher manipulates two or more variables simultaneously to study the independent effect of each variable on the dependent variable, as well as the effects caused by the interactions between multiple variables. In experimental class, the students will be taught using project-based learning (PJBL) model, while in the control class, conventional model will be used. The moderator variable will be the students' GPA. This research was carried out in the following stages:

The initial stage of this study was developing learning tools through 3 stages namely: the analysis stage of the students' 4Cs initial skills, the project-based learning design stage and the construction of PJBL learning tools such as lesson plan, Model Books and Learning Media. 


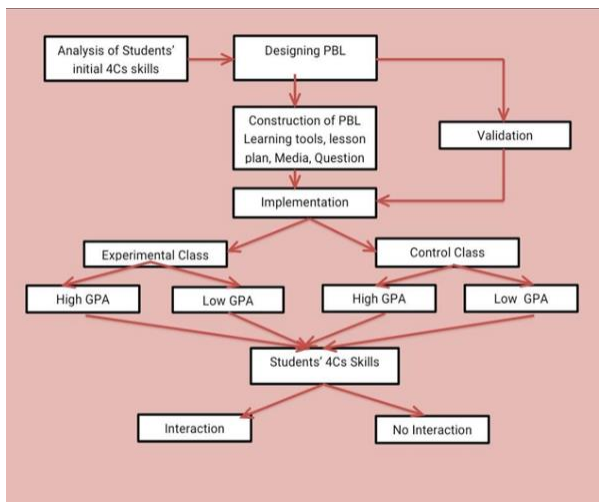

Figure 1 Research Steps in Analysing Abilit

\section{RESULT AND DISCUSSION}

\subsection{Analysis of students' 4Cs initial skills}

In the initial stage, an analysis of students' 4 Cs initial skills was carried out using standardized instruments to assess the initial conditions of students' Creativity, Critical Thinking, Communication \& Collaboration Skills (4Cs) skills. The result showed that students in the both experimental class and control class still had low 4 Cs abilities.

\subsection{Designing PJBL}

Designing PJBL Learning model required determination from the lecturer since it required a lot of preparation. Preparations that needed to be carried out included designing projects that must be completed by students. Besides, the project must be challenging and demanding so that it could sharpen their 4Cs skills. Learning design established was the result of studying various theories and the characteristics of the course; thus, learning activities using Project-Based Learning model were implemented as follows.

\subsection{Learning Preparation}

First, the students were triggered by asking question related to problem happening in their surroundings in order to encourage them to think critically. Then, students were divided into several groups so that they could build cooperation, communication, problem solving and design solutions [19]. To achieve learning objectives of Project-Based Learning which is 4 Cs skills, it is necessary to prepare a learning plan that allows students to achieve the expected outcome.

PJBL learning model can be implemented using 2 patterns:

1. Alternative I: Each meeting is conducted with a project-based learning principle based on the allocated time according to the workload of 1 credit, where 1 credit equal to 150 minutes $(3 \times 50$ minutes). If there are 3 credits in one week. Students' activities are about 450 minutes / 7.5 hours per week.

2. Alternative II: Learning Activities are conducted for 7 meetings in which two projects for each student are carried out in one semester. The steps of the project in each week are as follows:

a. Team division: Students choose their own group members consisting of 5 people in one group.

b. They choose their project based on the interests of each group. The themes can be the content in economics, management / commerce, office administration or accounting according to their expertise on Educational Research course. Meanwhile, other courses, such as development economics, are adjusted to the topics that have been compiled in the course syllabus.

\section{Meeting 1 Plan: Introduction}

Lecturers get to know the students, build an understanding of Project-Based Learning and explain the learning procedures for the next 6 weeks. Groups are asked to prepare topics or project ideas they are working on. Students discuss for 30 minutes to determine the project they will work on, and after that each group presents their ideas for 15 minutes and the lecturer and other students provide feedback, and input for improvement and guide the group members to find material, and data sources available in the community, environment and online sources on the internet.

\section{Meeting 2 Plan: Searching and Designing}

Each group member looks for data, does field surveys, designs suitable presentation and communication media during Covid-19, builds commitment among group members to appoint a task for each group member and then discusses their findings. Next step is writing scripts and finding sources for learning media. Supervisors (researchers) assist to confirm relevant theories or other technical matters. Lecturers prepare a syllabus for one semester according to the courses taught as references of problem solvers. The preparation of media to support implementation of PJBL includes:

1. Distribution of lecturer and tutor assignment.

2. Grouping students in class based on tutor.

3. Announcement of schedules and activities through the official page of the UNP Academic Portal.

4. Setting the room for online tutoring.

5. Setting room for virtual video (zoom, Google meeting, and other platforms)

\section{Meeting 3 Plan: Making product/ output}

Students make their products in the form of media (videos, props, articles) and compile learning media to be stored on Google Drive and shared in elearning.unp.ac.id on the discussion forum menu / tools. 


\section{Meeting 4 Plan: Sharing the Materials and Media.}

A member of each group shares a Google drive link for learning videos that they have compiled. They have maximum 15 minutes to read and listen to the learning video which is later discussed in their respective group discussions.

\section{Meeting 5 Plan: Presentation}

Each group presents the group's learning result in the form of a 15-minute video. The supervisor (researcher) provides advice on the forum panel available at elearning.unp.ac.id and evaluates the results of group work with existing theoretical arguments, and the analytical tools used to analyze the problems created by these students. Then, after they present and others open the learning video on the Google Drive link in the discussion forum panel, each student contributes in giving feedback, suggestions and input

\section{Meeting 6 Plan: Reflection and Follow-up Plan}

Each student is asked to write a reflection of their learning while doing and finishing the project. The reflections are mainly about learning experiences, the hindrances that they face during mid-term exam.

\subsection{Evaluation}

Learning Evaluation is carried out by paying attention to the 4Cs skills which are designed based on collected data to monitor how students work in groups, finish the project, do self-reflection and assess themselves and their peers.

\subsection{Learning Tool Validation}

The implementation of Project-Based Learning must be supported by the availability of learning tools such as lesson plan, learning media and question items as well as project assessment formats. Therefore, validation is carried out by validating material and language experts on learning devices, media, assessment instruments so that they are produced and get input on improving the device so that it is suitable for use in research. In this study, validation was carried out by 3 experts.

Based on expert validation, it was shown that TCR for the learning outcome was $90.02 \%$, which means that the learning outcome was in accordance with the skills of the 21 st century (4Cs). There was also a link between LO and the material presented. Moreover, learning outcome has described the cognitive level and LO could be achieved through learning activities that have been designed. In the aspect of pedagogical activity, the TCR was $83.33 \%$, which means that the lesson plan designed was feasible to use because the pedagogy activities were in accordance with the PJBL principles. Lecturers could carry out PJBL and students were able to take part in learning. Evaluation of PJBL has been in line with the LO.
In terms of the material, the percentage for development of lesson plan was $88.33 \%$. It means that it was very feasible to apply. The depth of the material presented has reached a high-level of critical thinking. The material taught was also able to encourage student creativity and it has been in accordance with the expected collaboration and communication skills. The material designed was also considered relevant to the conditions of the students. Furthermore, percentage for development of the evaluation in lesson plan reached $80 \%$, which means that the evaluation was designed correctly with the right weight of the assessment score and the appropriate assessment elements; hence, it could improve the expected Learning Outcome. However, evaluation aspect still needed slight improvement by adding detailed indicators to the assessment rubric for both LO and CLO.

Based on validation results, in terms of the readability the model book has fulfilled the readability aspect which was $100 \%$. Besides, the words written have been standardized and clear, and it did not use ambiguous language. Moreover, the model book could be easily understood. Overall, the model book met all the criteria required in a book. In addition, the feasibility of the contents of the book was 85 meaning that the book has been deemed fit to use. The feasibility aspects are supported by several indicators including the relevance of model book to the indicators being measured, the use of appropriate references, the appropriateness of arguments for adoption of learning models and learning outcomes, and lastly the learning steps guide which is in line with learning outcome.

The percentage of description of the implementation procedure reached $80 \%$, which means that the model book has described the correct implementation procedure. The implementation procedure is clearly and functionally defined. Moreover, the percentage of book presentation was 91.67, which means that the book presentation was feasible. The presentation aspect of this book was supported by good narrative indicators, good cover, good presentation of images and designs, and good systematics.

Overall, all aspects have been reviewed by the validators and the results showed good results which means that the model book is feasible to use. However, there is slight improvement needed in some areas. For example, in Chapter I it is necessary to add some references to the PJBL Syntax, the process of linking PJBL syntax with 4CS. Improvements to the images used in the model book to make it more visible is also required 
Table 1. Validity Result of Lesson Plan by Experts

\begin{tabular}{|c|c|c|c|c|}
\hline No & $\begin{array}{l}\text { Assessment } \\
\text { aspects }\end{array}$ & Description & Mean & TCR \\
\hline \multirow[t]{5}{*}{1} & Learning Outcomes & $\begin{array}{l}\text { Learning outcomes are appropriate and in } \\
\text { accordance with the skills in the } 21 \text { st century } \\
(4 \mathrm{Cs})\end{array}$ & 4.33 & 86.67 \\
\hline & & There is a relationship between LO and Material. & 4.67 & 93.33 \\
\hline & & LO has already described the Cognitive level & 4.33 & 86.76 \\
\hline & & LO is feasible. & 4.67 & 93.33 \\
\hline & & Average & & 90.02 \\
\hline \multirow[t]{5}{*}{2} & Pedagogy activity & $\begin{array}{l}\text { Pedagogical activities have been in line with } \\
\text { PBL principles }\end{array}$ & 4.33 & 86.67 \\
\hline & & PBL designed can be done by lecturers & 4.33 & 86.67 \\
\hline & & PBL designed can be completed by students. & 4.33 & 86.67 \\
\hline & & $\begin{array}{l}\text { PBL evaluation has been in accordance with } \\
\text { LO }\end{array}$ & 3.67 & 73.33 \\
\hline & & Average & & 83.33 \\
\hline \multirow[t]{5}{*}{3} & Material & $\begin{array}{l}\text { The depth of the material has reached a higher } \\
\text { order of critical thinking }\end{array}$ & 4.33 & 86.67 \\
\hline & & Materials encourage the students' creativity. & 4.33 & 86.67 \\
\hline & & $\begin{array}{l}\text { Materials are in accordance with the expected } \\
\text { communication and collaboration skills. }\end{array}$ & 4.67 & 93.33 \\
\hline & & $\begin{array}{l}\text { Materials are relevant with students' } \\
\text { circumstances. }\end{array}$ & 4.33 & 86.67 \\
\hline & & Average & & 88,33 \\
\hline \multirow[t]{5}{*}{4} & Evaluation & Peer assessment is correct & 4.00 & 80 \\
\hline & & The weight and assessment score are correct. & 4.00 & 80 \\
\hline & & Assessment elements are correct & 4.00 & 80 \\
\hline & & Assessment has described the LO & 4,00 & 80 \\
\hline & & Average & & 80 \\
\hline
\end{tabular}

Table 2. Validity Result of Model Book by Experts

\begin{tabular}{|c|c|c|c|c|}
\hline No & Assessment Aspects & Description & Mean & TCR \\
\hline \multirow[t]{5}{*}{1} & Model Book Readability & $\begin{array}{l}\text { The model book meets the legibility } \\
\text { requirements. }\end{array}$ & 5.00 & 100 \\
\hline & & $\begin{array}{l}\text { The words used are clear and meet the } \\
\text { requirement. }\end{array}$ & 5.00 & 100 \\
\hline & & Model book does not use confusing language. & 5.00 & 100 \\
\hline & & The model book is easily understood. & 5.00 & 100 \\
\hline & & Average & & 100 \\
\hline \multirow[t]{5}{*}{2} & Feasibility Book content & Model book is relevant to indicators measured. & 4.00 & 80 \\
\hline & & $\begin{array}{l}\text { Book Model is sourced from appropriate } \\
\text { references. }\end{array}$ & 4.67 & 93.33 \\
\hline & & $\begin{array}{l}\text { Argument for the adoption learning models } \\
\text { and learning outcome are in line. }\end{array}$ & 4.33 & 86.67 \\
\hline & & $\begin{array}{l}\text { Guidance steps of learning are in accordance } \\
\text { with Learning Objective. }\end{array}$ & 4.00 & 80 \\
\hline & & Average & & 85 \\
\hline \multirow[t]{3}{*}{3} & $\begin{array}{l}\text { Description of } \\
\text { Implementation Procedures }\end{array}$ & $\begin{array}{l}\text { The implementation procedures are clearly } \\
\text { defined. }\end{array}$ & 4.00 & 80 \\
\hline & & $\begin{array}{l}\text { The implementation procedures are } \\
\text { functionally defined. }\end{array}$ & 4.00 & 80 \\
\hline & & Average & & 80 \\
\hline \multirow[t]{5}{*}{4} & Book Presentation & The narrative is good & 4.67 & 93.33 \\
\hline & & The cover is good & 4.33 & 86.67 \\
\hline & & The presentation of images and design is good. & 4.33 & 86.67 \\
\hline & & The systematics is good & 5.00 & 100 \\
\hline & & Average & & 91.67 \\
\hline
\end{tabular}




\section{CONCLUSION}

From the study that has been done, the implementation of PJBL in learning provides several learning experiences that can encourage the growth of 4Cs. 1) students are required to be active in group discussions and personal activities during the learning process. Students are also required to be active in the WhatsApp group discussion in which the results of the discussion are presented in a joint forum discussion. 2) Learning activities that can be seen by lecturers are students' involvement in forums and other features provided; thus, students are expected to be actively involved in discussion forums and the quality of the arguments presented will be assessed. 3) In expression opinions or writing comments, students should base their opinions on certain references. 4) The students should check the assignment in plagiarism checker before submitting it, and lecturers should have Turnitin-based applications to check the authenticity of student writing. 5) The students should familiarize themselves using the Mendeley or Endnote application so that the writing will be neater and in accordance with standards and recommendation which is APA, 6) Students are active in asking questions and providing comments when they are on the online learning.

In addition to student learning experiences, the lecturers are also required to prepare and do some kinds of activities that can build students' 4 Cs skills. These are several activities done by the lecturers. 1) A team of lecturers in the field of expertise / subject groups need to discuss the lesson plan and the learning scenarios. 2) The lecturers prepare several topics that will be selected by the students in case they have not selected topic that will be discussed or studied in project. 3) Before entering the virtual classroom, the lecturer must prepare a learning video so that students can understand what is meant by written instruction of the lecturers. 4) The lecturers guide and explain the stages of the project, the process, and the output expected. 5) Lecturers must also be able to explain the evaluation and assessments that will be carried out for project. 6) Lecturers provide opportunities for students to ask questions via email, telephone, and WhatsApp messages. 7) Lecturers provide feedback and answer questions posed by students. 8) Lastly, lecturers provide reinforcement of student understanding so that the activities carried out are understood.

\section{REFERENCES}

[1] P. Griffin. ., B.,McGaw., \& Care. E, Assessment and Teaching of 21st Century Skills, 9789400723, 1-345. https://doi.org/10.1007/978-94-007-2324-5, 2012

[2] C. Kivunja, "Exploring the Pedagogical Meaning and Implications of the 4Cs "Super Skills" for the 21 centuries through Bruner's 5E Lenses of Knowledge Construction to Improve Pedagogies of the New Learning Paradigm". Creative Education, 06(02),
224-239.

https://doi.org/10.4236/ce.2015.62021, (2015)

[3] R.,Collins, Skills for the 21st Century: teaching higher-order thinking, 12(14). 2014

[4] Sajidan, S,.Widoretno, Ramli, M, \& Ariyanto, J. Kualitas Pertanyaan Dan Pernyataan Guru Dan Peserta Didik Sebagai Indikator Proses Berpikir Pada Pembelajaran Biologi Di SMA Surakarta, Laporan Penelitian PUPT, LPPM UNS, 2016

[5] Muhfahroyin, Pengaruh Strategi Pembelajaran Integrasi STAD \& TPS Dan Kemampuan Akademik Terhadap Hasil Belajar Kognitif Biologi, Kemampuan Berpikir Kritis, Dan Keterampilan Proses Siswa SMA Di Kota Metro. Disertasi. Tidak Diterbitkan. Malang: PPS Universitas Negeri Malang, 2009

[6] S.,Zubaidah, Mahanal, S., Suyanto, Yuwono, K.S., Dan Kurniyawati, E, Penerapan Pola PBMP (Pemberdayaan Berpikir Melalui Pertanyaan) Pada Mata Pelajaran IPA Untuk Meningkatkan Perkembangan Penalaran Siswa MIJS (Madrasah Ibtidaiyah Jenderal Sudirman) Malang, Lemlit UM, 2005

[7] S.,Mahanal, Zubaidah, S, Nugrahaningsih, Sunarmi, Tenzer, A, Penerapan Pembelajaran Berdasarkan Masalah dengan Strategi Kooperatif Model STAD Pada Mata Pelajaran IPA-Biologi Untuk Meningkatkan Keterampilan Proses Dan Kemampuan Berfikir Siswa SMA-SMA Dengan Setting Wilayah Pertanian Malang, Lemlit UM. 2006

[8] C.,Piawa, Y.Building, "A Test To Assess Creative And Critical Thinking Simultaneously", Procedia Social and Behavioral Sciences, 2(2), 551-559. https://doi.org/10.1016/j.sbspro.2010.03.062, 2010

[9] D.,Hotaman, "The Examination of the Basic Skill Levels of the Students' in Accordance with the Perceptions of Teachers, Parents and Students", International Journal of Instruction, 1(2), 39-56, 2008

[10] Sutirman, Media dan Model-Model Pembelajaran Inovatif. Graha Ilmu.Yogyakarta, 2013

[11] E.,Mulyasa, Guru Dalam Implementasi Kurikulum 2013. Bandung: PT. Remaja Rosdakarya, 2015

[12] Daryanto. Rahardjo, Mulyo, Model Pembelajaran Inovatif. Yogjakarta: Penerbit Gava Media, 2012

[13] D.,Yanti, E., Karyanto, P., \& Sugiharto, B, "Pengaruh Model Project Based Learning (PjBL) terhadap Kemampuan Berpikir Kritis Siswa Kelas X SMA Negeri 2 Karanganyar Tahun Pelajaran 2012/2013. BIO-PEDAGOGI", Jurnal Pendidikan Biologi, 2(2), 92-99. https://jurnal.uns.ac.id/pdg, 2013 
[14] J.,R.,Mergendoller, Markham, T., Ravitz, J., \& Larmer, J, Pervasive Management of Project Based Learning: Teachers as Guides and Facilitators. In $C$. M. Evertson \& C. S. Weinstein (Eds.), Handbook of classroom management: Research, practice, and contemporary issues (p. 583-615), Lawrence Erlbaum Associates Publishers, 2006

[15] W.S. Wibowo, "Implementasi Model Project-Based Learning (PJBL) Dalam Pembelajaran Sains Untuk Membangun 4Cs Skills Peserta Didik Sebagai Bekal Dalam Menghadapi Tantangan Abad 21", Seminar Nasional IPA V, 276-286, 2014

[16] U.S. Department of Education, Project based learning at harmony public schools, District Reform Support Network, 1-11, 2015

[17] M.A Samsudin, Md Zain, A. N., Jamali, S. M., \& Ebrahim, N. A, Physics Achievement in Stem Project Based Learning (PJBL): A Gender Study, Asia Pacific Journal of Educators and Education, 32, 2128. https://doi.org/10.21315/apjee2017.32.2, 2018

[18] N. P. N., Ekawati, Dantes, N., \& Marhaeni, A. A. I. N, Pengaruh Model Project Based Learning Berbasis 4c Membaca Pemahaman Pada Siswa Kelas IV SD Gugus III Kecamatan Kediri Kabupaten Tabanan. 3(1), 41-51, 2019

[19] G., Arcidiacono, Yang, K., Trewn, J., \& Bucciarelli, L, Application of Axiomatic Design For ProjectBased Learning Methodology. Procedia CIRP, 53, 166-172, 2016 